Pomaza-Ponomarenko A., Doctor of Science degree in Public Administration, Senior Researcher, National University of Civil Protection of Ukraine, Kharkiv, ORCID ID: 0000-0001-5666-9350,

Medvedeva D., Student, National University of Civil Protection of Ukraine, Kharkiv, ORCID ID: 0000-0003-1597-1857,

Drahan I., Doctor of Science degree in Public Administration, Professor, Head of the Department of Economic Security, Public Administration and Administration of Zhytomyr Polytechnic State University, Zhytomyr,

ORCID ID:

\title{
E-GOVERNANCE AS A AI-TOOL OF ESTABLISHING FEEDBACK WITH THE PUBLIC AND CONFLICT RESOLUTION
}

\section{Е-УРЯДУВАННЯ ЯК АІ-ІНСТРУМЕНТ НАЛАГОДЖЕННЯ ЗВОРОТНО- ГО ЗВ'ЯЗКУ З ГРОМАДСЬКІСТЮ ТА ВИРІШЕННЯ КОНФЛІКТІВ}

The article considers the theoretical foundations of an extremely important institutional process - e-government as a tool for using artificial intelligence (AI) technologies.Perspective directions of its use for establishing public relations and resolving conflicts are determined.

Keywords: e-government, public administration, public, conflicts.

У статті розглядаються теоретичні засади вкрай важливого інституційного процесу - е-урядування як інструмента використання технологій штучного інтелекту (AI). Визначено перспективні напрямки його застосування для налагодження зворотного зв'язку з громадськістю та вирішення конфліктів.

Ключові слова: е-урядування, публічне управління, громадськість, конфлікти.

Problem setting. Electronic Governance (hereinafter - e-governance) serves as the goal and the most important factor of administrative innovations [1]. Being creatured from the category of experimental technologies the e-government is steadily moving into the area of everyday use, although it is too early to talk about its total role in Ukraine. Its introduction in the system of state management of Ukraine should be carried out in a balanced and phased manner, taking into account the general scheme and positive experience of the leading countries of the world. Having regard to the modern terms of increase of meaningfulness of social, economic and informative functions of the state, including Ukraine, her institutes of all levels of management (state, regional and organizational) force to modify the culture of relationships with citizens. All aforesaid emphasizes the relevance of the research. 
Paper objective. However, it can't be carried out without providing of the profound and comprehensive analysis of the processes happening within the implementation of e-government. Thus, the main task of this research is to determine mechanisms for the introduction of e-governance into improving of the system of public management of Ukraine in the context of securing its social and protection sphere. This definition of the principles encompasses the study of world trends and Ukrainian dynamics of e-government development in modern conditions.

Paper main body. Many domestic and foreign scientists and practicians offer effective approaches to solution of various problems, which arise in the process of functioning of the mechanisms of public management of e-governance in present conditions. In particular, different authors pay significant attention to the essence of e-governance, its elements and also feature of its implementation and evaluate.

Some authors state that nowadays the e-governance is the developed instrument of marketing of many countries of the world. Its includes the broad system of organisational, legal, social and other relations, which arise and develop between the main subjects of market of services.

The state of the realization of e-governance within any society depends directly on a general economic situation in the country, as well as development of its information society. Therefore, the e-governance in the market of services sometimes is considered as a peculiar indicator of social-economic development of state and society, which must be evaluate.

The peculiarities of the introduction of e-governance in different countries of the world are also the subject of a study by UN representatives. In particular, a comprehensive indicator of its implementation was developed by the Department of Economic and Social Affairs. This indicator is estimated since 2003 and every two years (UN e-government surveys) [5].

It should be noted that despite the large number of scientific developments, opinions and thoughts, the national territory lacks research on the study of scientific and theoretical principles of formulation of culture of implementation of egovernment as a part of public management in the real socio-economic, humanitarian and socio-cultural environment of Ukraine. Today it faces the task of developing its own co-ordinated position about the e-governance model, taking into account the high dynamics of social and information processes.

"E-government" is a term that briefly describes the modern approach that emerged in the context of the development of information society to determine the role of government bodies and non-governmental institutions in the life of state and the socio-economic development of its regions. This term refers to a new way of organizing of public management, its transformation with an orientation towards a fundamentally closer relationship with citizens, a dramatic improvement in the realization of public authorities, greater efficiency of their actions and personification of responsibility. This method is based on the purposeful and coordinated application of new information and communication technologies for the realization of state's administrative (service-management) functions. 
E-governance may acquire such marketing and administrative forms as administrative services (for citizens, for business and special services), e-petitions, eeducation, e-budget, e-registry, etc. These forms determine the level of e-governance development. The level of e-governance development is different in the economically developed countries and the developing ones. According to the UN experts, it is possible to estimate its level based on the ERI (E-government Readiness Index) - maturity indicator [6]. It comprises of the following components:

1) Web measurement index (it determines the ability of delivering administrative services online, the possibility of using mobile applications for this, etc.);

2) Telecommunication infrastructure index (it assesses the level of availability of ICT means among the citizens, their development in the country and the relevant networks in the advanced countries);

3) Human capital index (it determines the level of education of citizens, including the education in the field of information technologies) [3-4].

It should be noted that the global leaders of the ERI change every year (Table 1). Nevertheless, after forming the relevant group of leaders in this field, the indicated countries proved that they had achieved success in the development of e-governance, in particular due to the complex and well-grounded approach to its implementation.

Table 1

State of introduction of e-governance in country-leaders based on the ERI in 2008-2018

\begin{tabular}{|c|c|c|c|c|c|c|c|c|}
\hline \multirow[t]{2}{*}{ № } & \multirow[t]{2}{*}{ Name of country } & \multicolumn{7}{|c|}{ Position in rating by ERI indicator } \\
\hline & & 2008 & 2010 & 2012 & 2014 & 2016 & 2018 & $\begin{array}{l}\text { Change } \\
\text { in 2018, } \\
\text { compared } \\
\text { to } 2008\end{array}$ \\
\hline 1 & Australia & 5 & 6 & 11 & 2 & 2 & 3 & $\uparrow 2$ \\
\hline 2 & UK & 7 & 2 & 3 & 8 & 1 & 9 & $\downarrow 2$ \\
\hline 3 & Estonia & 9 & 11 & 4 & 7 & 11 & 5 & $\uparrow 4$ \\
\hline 4 & Netherlands & 3 & 3 & 2 & 5 & 7 & 6 & $\downarrow 3$ \\
\hline 5 & New Zealand & 10 & 9 & 10 & 10 & 8 & 7 & $\uparrow 3$ \\
\hline 6 & South Korea & 4 & 1 & 1 & 1 & 3 & 8 & $\downarrow 4$ \\
\hline 7 & Singapore & 11 & 7 & 8 & 3 & 4 & 1 & $\uparrow 10$ \\
\hline 8 & Finland & 2 & 4 & 9 & 9 & 5 & 10 & $\downarrow 8$ \\
\hline 9 & France & 6 & 6 & 6 & 4 & 10 & 11 & $\downarrow 5$ \\
\hline 10 & Sweden & 1 & 8 & 7 & 11 & 6 & 2 & $\downarrow 1$ \\
\hline 11 & Japan & 8 & 10 & 5 & 6 & 9 & 4 & $\uparrow 4$ \\
\hline 12 & $\begin{array}{l}\text { World average } \\
\text { ERI }\end{array}$ & 0,42 & 0,41 & 0,48 & 0,47 & 0,49 & 0,49 & $\uparrow 0,07$ \\
\hline
\end{tabular}

Source: [5] 
From the analysis of Table 1 it can be seen that the global E-government Readiness Index changes all the time increasing gradually almost every year.

In Ukraine, the dynamics of this index is quite ambiguous, as there is its constant fluctuation sometimes up, sometimes down (fig. 1). According to the UN's latest data, based on ERI, Ukraine was 41rd among 193 countries in 2008, 54rd in 2010, 68th in 2012, 87th in 2014, and 62th in 2016 [5].

Despite the insignificant changes in comparison with 2016, it is possible to state that Ukraine lags behind the global rates of the development of electronic services considerably, and that it is necessary to develop the single coordinated state policy in this field aimed at the solution of top-priority problems.

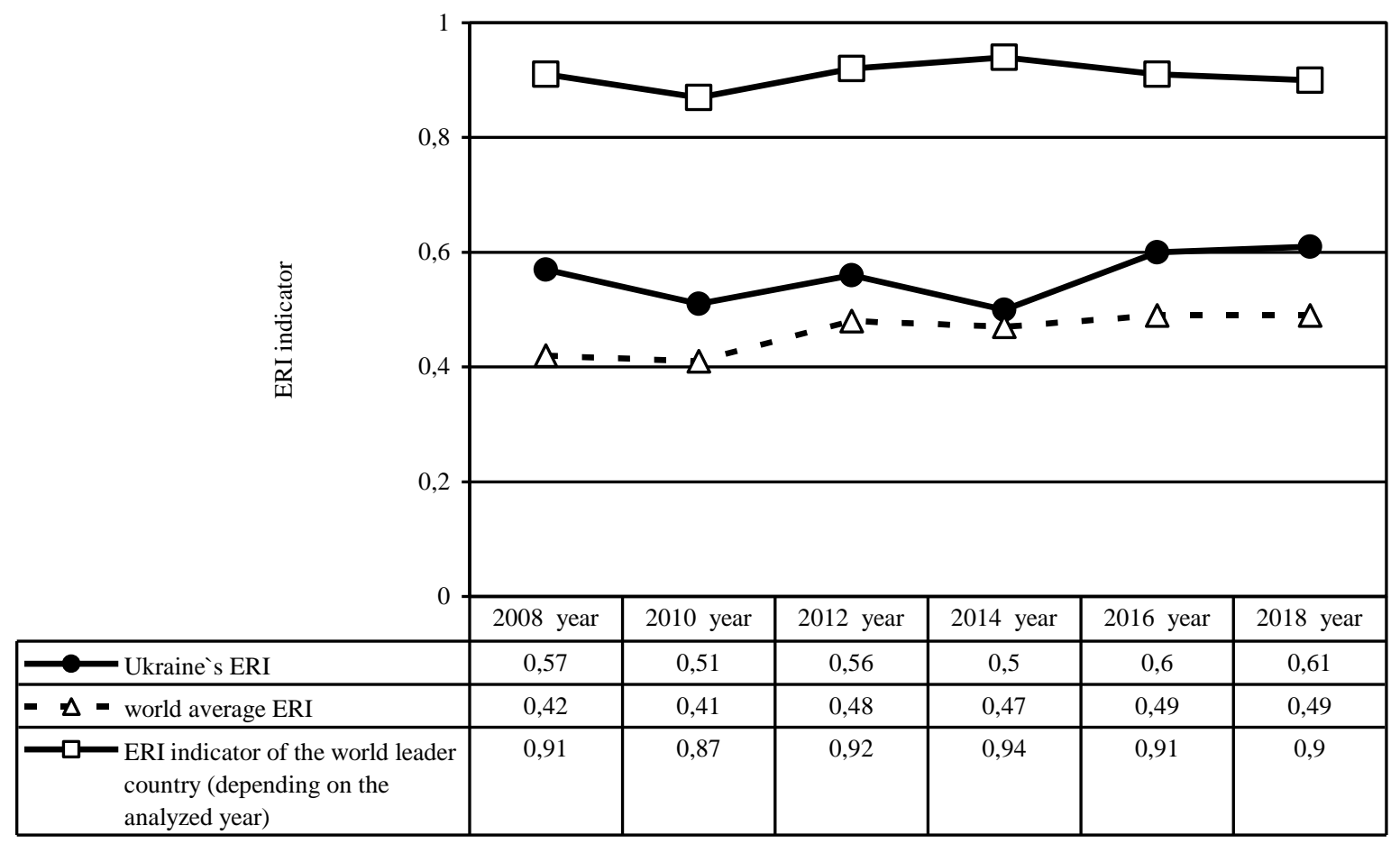

\section{Fig. 1. Ukraine's ERI dynamics and world average, as well as ERI indicator of the world leader country for 2008-2018}

Source: [2]

Analysis of the legal framework and practice of e-government in Ukraine suggests a number of problems related to management aspects, and, above all, the nonsystematic assessment of e-readiness of Ukraine, in particular on indicators of ICT use in education, human rights and other areas of society, and, consequently, the failure to take into account the components of the ERI indicator in it, which is proposed by UN experts. Given this, we can propose to improve the legal framework for the development of e-government in Ukraine. This is possible due to the scientific conceptualization of the development of domestic mobile applications, in particular, "Action". This application can be used like the Chinese application "WeChat", which covers the possibility of simplified money transfers, including as a salary, as well as the 
possibility of online marriages, going to court, etc. [1; 3-4]. Thus, the domestic "Action" can ensure the appropriate level of socio-economic development of Ukraine through the use, in particular, artificial intelligence algorithms.

Conclusions of the research. In this work we studied out the scientific and theoretical substantiation of e-government as a component of state management, as well as perspective directions of its introduction in conditions of transformation of educational, protection of rights and others systems in Ukraine. This allows us to formulate the following conclusions:

1. It is established that since 2008 Ukraine lags behind the global rates of the development of electronic services considerably, and that it is necessary to develop the single coordinated state policy in this field aimed at the solution of top-priority problems. They are related to the complexity of monitoring and evaluation of education sphere, the provision of "relevant" (actual) knowledge in higher education, the quality of distance education (the features of which began to pay active attention during the virus COVID-19), the growth of labor market innovation etc.

2. A separate block identifies measures related to the formation of a culture of e-government in the human rights system, which requires more active and widespread use of public mobile applications, in particular, "Action". It can be used on the same principle as the "WeChat" application in China.

3. The main conclusion is that the processes of implementing of e-governance, as well as improving of public management in social, educational, human rights spheres should take place in parallel, in close connection with each other and based on common principles within a single of mechanism.

\section{References:}

1. Помаза-Пономаренко А. Л., Медведєва Д.О. Е-система публічного управління України або особливості застосування штучного інтелекту в ній. Публічне адміністрування та наиіональна безпека. 2021. № 1 (17). URL: https://www.internauka.com/issues/administration2021/1/6827.

2. Benchmark Global E-Government Development - 2018 UN e-Government Survey, 2018.

URL: http://workspace.unpan.org/sites/Internet/Documents/UNPAN97854.pdf.

3. Pomaza-Ponomarenko A., Hren M., et. all. Management mechanisms in the context of digitalization of all spheres of society. Revista San Gregorio. SPECIAL EDITION2020. №42.

URL: http://revista.sangregorio.edu.ec/index.php/REVISTASANGREGORIO/issue/view/ RSAN42/showToc.

4. Pomaza-Ponomarenko A., Hren M., Durman O., Bondarchuk N., Vozniuk E. Problematic aspects of state policy modernization in the conditions of digitalization. International Journal of Management, 2020. № 11 (6). P. 508-515.

5. UN e-Government Surveys. Public Institutions and Digital Government of Department of Economic and Social Affairs of UN, 2018. URL: https://publicadministration.un.org/en/research/un-e-government-surveys. 